\title{
Study on Monitoring and Warning System of Karst Water Bursting Disaster in Karst Area
}

\author{
Chengliang WANG ${ }^{1, a}$, Mingzhou BAI ${ }^{1, b}$ and Chengyong YANG ${ }^{1, c}$ \\ ${ }^{1}$ School of Civil Engineering, Beijing Jiaotong University, Beijing 100044, China \\ a362531360@qq.com, bmzhbai@bjtu.edu.cn, cchyyang@bjtu.edu.cn
}

\begin{abstract}
Keywords: Karst tunnel; Karst water bursting disaster; monitoring and warning
Abstract : Rely on major projects such as the Shanghai-Kunming high-speed railway, the paper studies the method and system of monitoring and warning of Karst water bursting disasters in high risk tunnel. Taking water pressure, water inflow and surrounding rock deformation as warning indicators, the paper studies the classification of warning grade and warning index of Karst water bursting disaster. With the stacking and coupling analysis between monitoring data of warning indexes and conclusion of risk assessment, Karst water bursting disaster during tunnel construction monitoring and warning system is established. The feasibility and practicability of this method are verified by case analysis. It has important reference value for the construction and design of similar tunnel engineering.
\end{abstract}

\section{Introduction}

In the process of deep buried tunnel construction in Karst area, it is an important method to take effective monitoring and precaution measures to prevent Karst water bursting, as well as an important measure to reduce construction risks. China has built nearly ten thousand kilometers of railway tunnel, through a variety of complex geological conditions, of which has most engineering influence and highest risk problem is Karst water and mud bursting disaster. In recent years, there have been more than 100 accidents of water inrush from the railway tunnels, resulting in the large casualties and economic losses, which seriously affect the normal operation of the project. How to successfully predict and forecast the geological disasters of Karst water bursting, and to avoid the accident, is the outstanding problem of tunnel engineers.

In view of the lack of in-depth and systematic research on the technology and method of monitoring and warning of Karst water bursting disasters at high risk and complex tunnel in Karst area, carrying out the risk monitoring and warning of the Karst water bursting disaster in the construction period of the mountain railway tunnel project is of great significance for the prevention and safety of the tunnel construction.

\section{Monitoring and warning system of Karst water bursting disaster}

\section{Monitoring and warning system of Karst water bursting disaster}

By studying the analysis of influence and control factors of Karst water bursting disaster in railway tunnel, the main types and basic models of water hazard in the Karst water bursting in railway tunnel are made clear. By collecting, sorting, analyzing and summarizing critical warning index feature and warning level such as geological conditions of typical railway engineering cases, the warning level of Karst water bursting disaster and critical warning index are established, and the typical Karst water inrush disaster monitoring and warning model is determined.

On the results of the survey sample, index critical threshold and characteristic value of tunnel Karst water bursting disaster is statistically analyzed to apply to coupling model to study on the warning model of Karst water bursting disaster. The main contents of the monitoring and warning system include 5 aspects: monitoring, identification, assessment, early warning and countermeasures. It is a complicated system, which is composed of many factors. There is a relationship of mutual influence and mutual dependence. System components are shown in Fig. 1. 


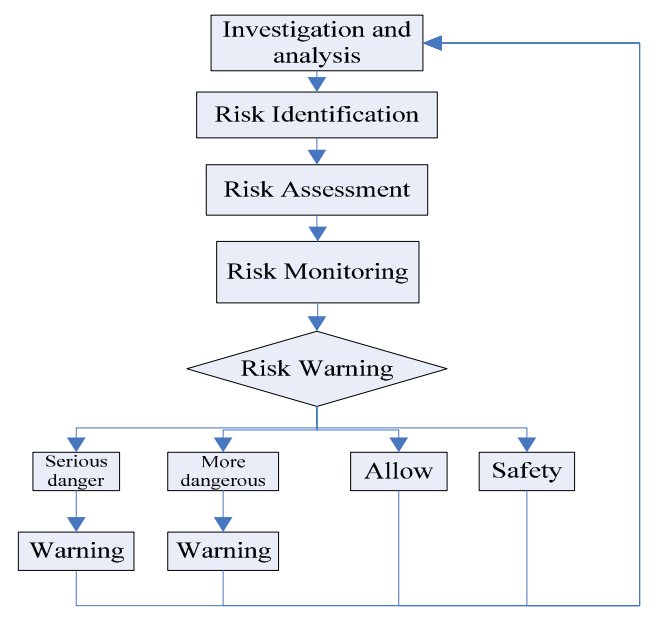

Fig.1. The working sketch of Karst water bursting geological disaster monitoring and warning system

Warning level of Karst water bursting disaster

Referring to land resources industry geological disaster classification criteria and grade division of geological hazard warning and forecast of China Meteorological Bureau, combined with characteristics of Karst water bursting disaster in tunnel engineering, the paper puts forward "red, yellow, blue and green" four - color geological hazard warning level based on the classification of Karst water bursting disaster risk assessment in tunnel construction, as shown in table 1.

Table1. Warning classification standard of tunnel Karst water bursting geological disaster

\begin{tabular}{|c|l|}
\hline Warning level & \multicolumn{1}{c|}{ Definition } \\
\hline $\begin{array}{c}\text { Level 1: Red } \\
\text { Warning }\end{array}$ & $\begin{array}{l}\text { It is an especially serious warning level that may cause especially serious safety accident and tunnel } \\
\text { construction catastrophic consequences. Generally it occurs in the Karst water bursting hazard risk } \\
\text { level I district. When happened, we should immediately release warning information, suspense } \\
\text { construction, evacuate equipment and personnel, develop and take the corresponding risk response } \\
\text { measures. }\end{array}$ \\
\hline $\begin{array}{c}\text { Level 2: } \\
\text { Yellow }\end{array}$ & $\begin{array}{l}\text { It is a serious warning level that may cause serious safety accident and seriously affect the tunnel } \\
\text { construction. Generally it occurs in the Karst water bursting hazard risk level II district. When } \\
\text { happened, we should immediately release warning information, suspense construction, pay close } \\
\text { attention to the monitoring data of the disaster point, and carry out emergency preventive measures. }\end{array}$ \\
\hline $\begin{array}{c}\text { Level 3: Blue } \\
\text { Warning }\end{array}$ & $\begin{array}{l}\text { It is a moderate warning level that may cause relatively heavier consequences. Generally it occurs in the } \\
\text { Karst water bursting hazard risk level III district. When happened, we should immediately release } \\
\text { warning information and remind the relevant construction and responsible personnel to pay attention to } \\
\text { the changes of the disaster point monitoring data. }\end{array}$ \\
\hline $\begin{array}{c}\text { Level 4: } \\
\text { Wareen }\end{array}$ & $\begin{array}{l}\text { It is a general warning level which has little damage and little impact on the construction. Generally it } \\
\text { occurs in the Karst water bursting hazard risk level IV district and have no need to release warning } \\
\text { information. }\end{array}$ \\
\hline
\end{tabular}

\section{Monitoring and warning indexes of Karst water bursting disaster}

The scale and harm of water bursting disaster in tunnel construction period has close relationship with Karst cave, underground river water rich fault zone and other factors. And the warning index, such as water quantity, water pressure, deformation of surrounding rock, is the most direct reflection of Karst water bursting disaster. Based on the existing research results, the warning indicators are selected from the water inflow, water pressure and surrounding rock deformation during the tunnel construction in the Karst area. Take real time monitoring of these indicators and refer to the risk level of geological disasters for each index to divide four levels, of which the level I is particularly serious, the level II is serious, the level III is moderate, and the level IV is mild.

(1) Water pressure monitoring and warning criteria

During drilling construction, bad water containing plastid ahead of working face will occur high pressure water gushing. Generally speaking, the greater the water pressure, the more remarkable the rock damage, the more the water pressure increases, the greater the probability of the Karst water bursting disaster. $P_{0}$ is the critical water pressure of aquiclude in front of working face in tunnel, $P$ is 
the measured water pressure. According to the variation trend of water pressure, the water pressure monitoring and warning standards are determined as shown in table 2.

Table2. Monitoring and warning standard of the water pressure

\begin{tabular}{|c|c|c|}
\hline $\begin{array}{c}\text { waming index } \\
\text { level }\end{array}$ & $\begin{array}{c}\text { Water pressure value and its } \\
\text { changing trend }\end{array}$ & waming measures \\
\hline I & $80 \% P_{0}<P<P_{0}, \Delta P \geq 0$ & Stop construction, take measures \\
\hline II & $80 \% P_{0}<P<P_{0}, \Delta P<0$ & Suspense construction, strengthen monitoring \\
\hline III & $P<80 \% P_{0}, \Delta P \geq 0$ & Construction and strengthen monitoring \\
\hline IV & $P<80 \% P_{0}, \triangle P<0$ & Normal construction \\
\hline
\end{tabular}

(2)Water quantity monitoring and warning criteria

Water inflow from bad water containing plastid ahead of working face directly affects the severity of Karst water bursting disaster. In the tunnel occurring Karst water bursting, often the higher the amount, the higher the level of disaster. Therefore, water inflow is the main index of Karst water bursting disaster monitoring and warning. According to the case of Karst water bursting disaster, the monitoring and warning standards for water inflow are shown in table 3.

Table3. Monitoring and warning standard of the water inflow

\begin{tabular}{|c|c|c|}
\hline $\begin{array}{c}\text { warning index } \\
\text { level }\end{array}$ & Water inflow $(Q)$ and Water quality change trend & warning measures \\
\hline I & $Q \geq 1 \times 10^{4} \mathrm{~m}^{3} / \mathrm{h}$, water is muddy or from clear to muddy & Water inrush, stop construction \\
\hline II & $\begin{array}{c}1 \times 10^{3} \mathrm{~m}^{3} / \mathrm{h} \leq Q<1 \times 10^{4} \mathrm{~m}^{3} / \mathrm{h}, \text { water is muddy or from clear to } \\
\text { muddy }\end{array}$ & $\begin{array}{c}\text { Water inflow to water inrush, } \\
\text { strengthen monitoring }\end{array}$ \\
\hline III & $\begin{array}{c}1 \times 10^{2} \mathrm{~m}^{3} / \mathrm{h} \leq Q<1 \times 10^{3} \mathrm{~m}^{3} / \mathrm{h}, \text { water is clear or has less mud and } \\
\text { sand }\end{array}$ & $\begin{array}{c}\text { Water inflow, strengthen } \\
\text { monitoring }\end{array}$ \\
\hline IV & $Q<1 \times 10^{2} \mathrm{~m}^{3} / \mathrm{h}$ & Normal construction \\
\hline
\end{tabular}

(3)Surrounding rock deformation monitoring and warning criteria

Referring to related research results of deformation of tunnel surrounding rock and related specification of displacement in Technical Guideline for construction of Highway Tunnel(JTG F60 - 2009), warning criteria for the monitoring of surrounding rock displacement in tunnel construction determined are shown in table 4.Among them, $U_{0}$ is designed limit amount of deformation, $U$ is the measured deformation.

Table4. Monitoring and warning standard of the displacement of surrounding rock

\begin{tabular}{|c|c|c|}
\hline $\begin{array}{c}\text { warning index } \\
\text { level }\end{array}$ & $\begin{array}{c}\text { Surrounding rock } \\
\text { deformation }\end{array}$ & warning measures \\
\hline I & $2 U_{0} / 3 \leq U$ & Stop construction, take measures \\
\hline II & $U_{0} / 2 \leq U<2 U_{0} / 3$ & Suspense construction, strengthen monitoring \\
\hline III & $U_{0} / 3 \leq U<U_{0} / 2$ & Construction and strengthen monitoring \\
\hline IV & $U<U_{0} / 3$ & Normal construction \\
\hline
\end{tabular}

\section{Coupling warning method of Karst water bursting disaster}

Combined with risk assessment and warning indexes of Karst water bursting hazard in the study area, coupling the two to form Karst water inrush disaster monitoring and warning level of research area. The results are shown in table 5.Monitoring and warning system of Karst water bursting disaster in the study area coupling the real-time monitoring of the early warning indicators and the risk level of the study area and get warning level of each block. The system use different colors to display monitoring and warning area at all levels to send warning information to the use of personnel.

Table5. Coupling model of warning level

\begin{tabular}{|c|c|c|c|c|c|}
\hline \multicolumn{2}{|c|}{ Warning level } & \multicolumn{4}{|c|}{ Risk assessment level } \\
\cline { 3 - 6 } & I & level 1 warning & level 1 warning & level 1 warning & level 2 warning \\
\hline \multirow{3}{*}{$\begin{array}{c}\text { warning } \\
\text { index level }\end{array}$} & II & level 1 warning & level 1 warning & level 2 warning & level 3 warning \\
\cline { 2 - 6 } & III & level 1 warning & level 2 warning & level 3 warning & level 4 warning \\
\cline { 2 - 6 } & IV & level 2 warning & level 3 warning & level 4 warning & level 4 warning \\
\hline
\end{tabular}




\section{Case analysis of monitoring and warning of Karst water bursting disaster}

D1K871+775 D1K871+835 of Gangwu tunnel is located in erosive mid mountain valley and gully. In this area, the main characteristic is that carbonate rocks are widely distributed and is tectonic erosion to Karst valley landform. D1K870+772 D1K873+745 section has an average rainfall of $1482.3 \mathrm{~mm} / \mathrm{a}$. Its predicting normal water inflow is about $15410.3 \mathrm{~m}^{3} / \mathrm{d}$ and maximum water inflow is $38525 \mathrm{~m}^{3} / \mathrm{d}$. The risk assessment of Karst geological disaster inD1K871+775 D1K871+835 of Gangwu tunnel is level I, that is, the serious risk level.

In April 25, 2012 when upper stage working face of Gangwu tunnel was constructed to D1K871+805, on the left side of the line a semi filled Karst cave is revealed. The caves are mainly developed in the tunnel bottom and the right side of the line and left lower than right. Caves on the left developed $8 \mathrm{~m}$ below the tunnel bottom and the right side develop $55 \mathrm{~m}$ outside the side wall and gradually develop to $5 \mathrm{~m}$ above the vault. At the bottom of cave filling piled block clay caused by wall collapsing. The distant wall was seeping water. In the evening of July 12th there was a rainstorm, causing a small and gradually enlarge water inflow in the cave. In the morning of July 13th 6:00, the water inflow was about $100 \mathrm{~m}^{3} / \mathrm{h}$. While in $6: 30$, the water inflow suddenly and sharply increased. According to the result of field monitoring, the depth of pavement outflow was about $60 \mathrm{~cm}$ with a velocity of $3.5 \mathrm{~m} / \mathrm{s}$ and inflow of $57000 \mathrm{~m}^{3} / \mathrm{h}$.

According to the conclusions of risk assessment and monitoring and warning data, command and project department started first level warning (red warning) scheme and evacuated field equipment and personnel immediately. Around 11 a.m. the inflow of water is reduced to about $15000 \mathrm{~m}^{3} / \mathrm{h}$ and gradually and decreased until 22:00 there was no water outflow from adit. In the process of water bursting, the spoil field construction site was destroyed and a muck car was rushed to the ditch. The whole process of water inflow changing is shown in Fig.2.Water bursting sites are shown in Fig.3.

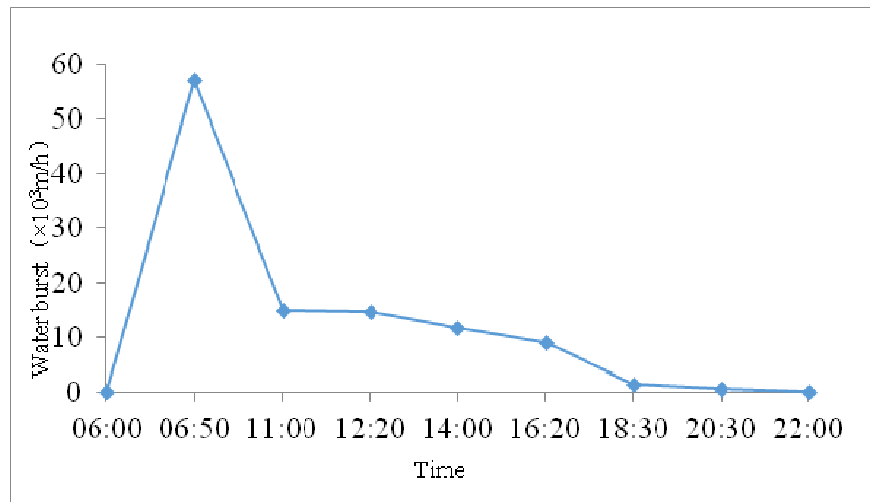

Fig.2. Water burst of D1K871+775 D1K871+835 in GangWu tunnel

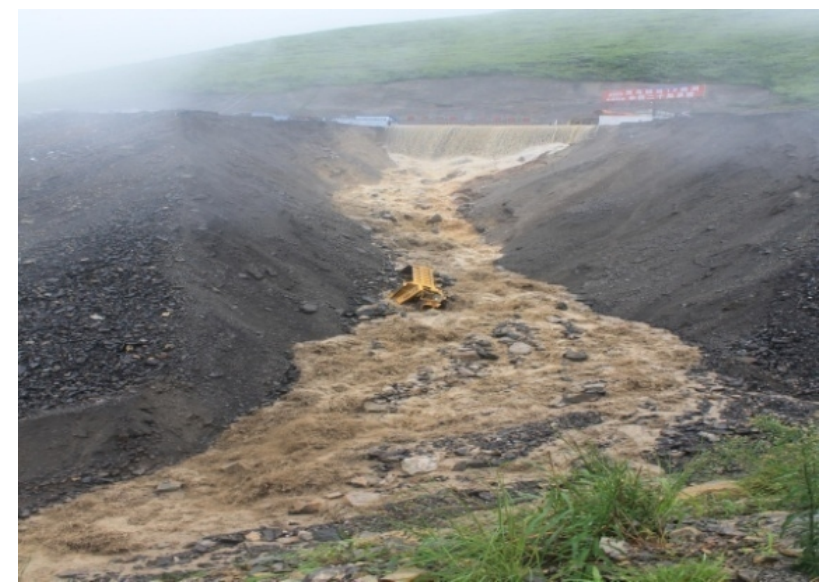

Fig.3. Construction site burst 


\section{Conclusions}

(1) By studying the analysis of influence and control factors of Karst water bursting disaster in railway tunnel, the warning index system and index classification standard of Karst water bursting disaster are established and the classification criteria of Karst water bursting hazard warning is put forward.

( 2 ) Based on the classification of Karst water bursting disaster risk assessment in tunnel construction, the paper puts forward "red, yellow, blue and green" four - color geological hazard warning level。

(3) Take the water inflow and water pressure, the surrounding rock deformation as warning index, with the real-time monitoring data, through the stacking and coupling analysis between monitoring data of warning indexes and conclusion of risk assessment, Karst water bursting disaster during tunnel construction monitoring and warning system is established.

\section{Acknowledgements}

This work was financially supported by the National Natural Science Foundation (NSFC) of China (No. 41372351 ).

\section{References}

[1] LI Shucai, XUE Yiguo, et al. Key Technology Study on Comprehensive Prediction and Early-warning of Geological Hazards During Tunnel Construction in High-Risk Karst Areas[J]. Chinese Journal of Rock Mechanics and Engineering, 2008, 27(7): 1297-1307.

[2] WANG Mengshu. Hydrogeological and geological forecast of tunnel construction in the karst district[J]. Railroad Survey, 2004, (1):7-10.

[3] ZHANG Jixun, REN Xuhua, JIANG Hongdao, et al. Main geological problems in diversion tunnel construction at Jinping II Hydropower Station[J]. Advances in Science and Technology of Water Resources, 2006, 26(6):66-70.

[4] LI Shucai, LI Shuchen, ZHANG Qingsong, et al. Forecast of karst- fractured groundwater and defective geological conditions[J]. Chinese Journal of Rock Mechanics and Engineering, 2007, 26(2):217-225.

[5] LIU Zhigang, ZHAO Yong. Geological technique for tunnel construction[M]. Beijing : China Railway Publishing House,2001.

[6] ZHAO Yonggui, LIU Hao, SUN Yu, et al. Research progress in tunnel geological advanced prediction[J]. Progress in Geophysics, 2003, 18(3):460-464.

[7] LIU Chuanxiao. Research and application of geological radar to predict key strata and to analyze fault parameters[J]. Coal Science Technology, 2005, 33(2): 21-23.

[8] BROOKS J W. Applications of GPR technology to humanitarian demising operations in Cambodia: some lessons learned[R]. [S. 1.]: Brooks Enterprises International, Inc., 1996:1-9.

[9] XUE Yiguo, LI Shucai, ZHANG Qingsong, et al. Application of TSP advanced prediction to tunnel in karst areas[J]. Chinese Journal of Underground Space and Engineering, 2007 , 21(6):1187-1191.

[10] XIAO Shu'an, WU Shilin. Geological prediction technique for tunnel construction under complex geological conditions[J]. Chinese Journal of Engineering Geophysics , 2004,1(2):159-165. 